\title{
A Análise Lingiística na Perspectiva da História: O Outro no Dizer do Cronista do Renascimento
}

\author{
Luiz Carlos FERNANDES \\ Universidade Estadual de Londrina
}

\begin{abstract}
Resumo: As relações entre os estudos lingüísticos e históricos são pensadas com base na idéia de que o discurso constitui uma prática e, enquanto tal, o seu sujeito apenas adquire identidade nele e durante o processo de sua composição em forma de palavras. A análise procura apontar, na estrutura enunciativa de enunciados do Tratado do Brasil, de Gabriel Soares de Soares, marcas discursivas que permitem reconhecer a vinculação do discurso quinhentista português com a formação ideológica então predominante. Trabalhos como este, sobre as marcas lingüísticas de documentos históricos, podem abrir novas possibilidades para uma maior aproximação entre as pesquisas nesses dois campos de conhecimento dos estudos humanísticos.

Palavras-chave: enunciação; histórica; formação discursiva; colonização; crônica de viagem.
\end{abstract}

\begin{abstract}
To evaluate the relationship between linguistic and historical studies, we consider, in that article, the idea that discourse composition constitutes a practice; therefore, involves an actor named "discourse subject". He acquires his individual identity by means of the choices he makes at the moment he constructs his speech. We try to make visible, among the enunciative structures of Gabriel Soares de Sousa's "Tratado do Brasil", evidences of predominant European ideological values in XVIth century. The approximation between linguistic and history studies can open good possibilities for both these areas of humanistic knowledge.
\end{abstract}

Key words: enunciation; history; discourse analysis; history; XVI century chronicles. 
"o sentido é determinado pelas posições ideológicas colocadas em jogo no processo sócio-bistórico em que palavras, expressões, proposições são produzidas (isto é reproduzidas)"

(Pêcheux, 1995, p. 160)

\section{Lingüística e História: Documento x Monumento}

As marcas de dizer presentes no discurso da crônica de viagem do século XVI evidenciam as possibilidades de um intercâmbio entre os estudos lingüístico-discursivos e os da História no que se refere à memória e à identidade nacionais. Os textos sobre o mundo americano recém-descoberto constituem acontecimentos discursivos cujas condições de produção, situadas no contexto institucional de um período histórico bastante peculiar, repercutem a coação explícita de valores ideológicos do quadro sócio-histórico em suas formas de representar, nas relações de força e nas estratégias discursivas visadas por esses enunciadores.

Quando se estudam fenômenos lingüísticos de dimensão superior à da frase, é necessário situá-los em uma dimensão que extrapole o domínio lingüístico: segundo Pêcheux (1993), sua natureza abarca também as relações extralingüísticas, as quais, paradoxalmente, tanto fazem parte deles como são constituídas por eles. Afinal, o discurso constitui uma prática e apresenta, enquanto tal, um conjunto de regras que envolvem e submetem o sujeito a partir do momento em que ele passa a tomar parte de seus processos: o sujeito adquire identidade no e pelo discurso. A forma de tratamento que se reserva aos fatos do passado histórico, de acordo com tal abordagem lingüística, inclui procedimentos discursivos desenvolvidos segundo um tipo de relação que permite ir além da simples análise de dados esparsos. Com base nessa visão, procura-se reconstituir, neste trabalho, indícios da formação ideológica predominante no quadro da formação social da Europa de fins do século XV, considerado o entorno do discurso cronístico dos viajantes.

Ainda que a Lingüística não consiga nos levar à descoberta, no sentido próprio do termo, das grandes alterações culturais e políticas que constituem o pensamento renascentista europeu e especialmente português, cremos que, com sua ajuda, se torne possível regularizar-se, 
normalizar-se, formalizar-se o que está na maioria dos textos do universo discursivo da época do Renascimento. $\mathrm{O}$ que ela pode oferecer a quem se debruça sobre esses textos do passado é um protocolo de técnicas, de métodos que ajudam a organizar, segundo um formato até certo ponto lógico, o dado bruto do texto. Com isso, talvez se possa demonstrar, com maior rigor, aquilo que a intuição e a leitura instrumentada do mesmo deixa sugerido. Caberá ao historiador reassumir, em seguida, todos os seus direitos no momento da interpretação, quando, em função de suas hipóteses, de suas pesquisas e dos resultados fornecidos pela análise lingüística, proporá seus resultados e sua tese.

Segundo LeGoff (1996), desde seu nascimento, a ciência histórica sempre se definiu em relação a uma realidade que não é observável como nas ciências da natureza e da vida: apenas no século $\mathrm{XX}$, o fato histórico passou a ser visto também como a possibilidade da sociedade do passado manipular a memória e o futuro. Até então, a História ignorava a possibilidade de uma busca das marcas do passado no presente por meio de objetos dados e acabados. Para ela, teria sido Certeau quem identificou a história enquanto prática social, contribuindo para que se passasse a considerar a hipótese de articular a leitura da história do mundo com a vontade de transformá-lo.

O historiador francês destaca a grande contribuição de Michel Foucault aos estudos de História, particularmente sua redefinição do "documento", bem como sua crítica à simples memorização dos monumentos do passado, que antes eram transformados em documentos. Graças ao pensador francês, a noção de descontinuidade passou a adquirir papel de maior relevo entre as disciplinas históricas, particularmente por questionar a possibilidade da existência de uma história global, provocando a introdução de métodos que levam a uma nova classificação do conjunto de problemas metodológicos. A estrutura da história-genealogia de Foucault viria a estruturar de outro modo a matéria da sociedade, da economia, etc., com o que passam a ser enfatizados estudos das práticas em detrimento das divisões em séculos, povos e civilizações.

Acreditou-se, durante largo tempo, que os verdadeiros documentos históricos fossem aqueles referentes aos grandes acontecimentos, à vida dos grandes homens, a acontecimentos militares, 
batalhas e tratados da história política e institucional. Hoje, porém, o historiador aprendeu a reconhecer a necessidade de se interpretar o significado dos documentos, de se avaliar a competência do autor, a sinceridade, a exatidão, além de se preferir examinar minuciosamente as suas condições de produção. Não se ignora também o poder de perpetuação que o documento pode exercer sobre a memória futura e nem a possibilidade do mesmo ser desmontado e identificado por completo pelo historiador; mas principalmente o fato de que nenhum documento é inocente.

Foucault propôs uma nova tarefa ao historiador no trabalho com os documentos, ao pregar que a história é "o que transforma os documentos em monumentos", e sugerindo que eles fossem transformados em conjuntos depois de isolados, reagrupados, tornados pertinentes e colocados em relação.

O documento adquire valor de testemunho ao ser selecionado: longe de ser inócuo, deve ser tomado, antes de mais nada, como o resultado de uma montagem, consciente ou inconsciente, da história, da época, da sociedade que o produziram, mas também das épocas sucessivas durante as quais continuou a viver, talvez esquecido, durante as quais continuou a ser manipulado, ainda que pelo silêncio. $\mathrm{Na}$ condição de monumento, o documento resulta do esforço das sociedades históricas para impor ao futuro, voluntária ou involuntariamente, determinada imagem de si próprias.

Para Le Goff (1996), qualquer documento é, ao mesmo tempo, verdadeiro (incluindo o falso) e falso, porque um monumento é, em primeiro lugar, uma roupagem, uma aparência enganadora, uma montagem: por isso, é preciso começar por desmontar, demolir esta montagem, desestruturar esta construção e analisar as condições de produção dos documentos-monumentos. Considera, porém, até mais necessário de que esses modos múltiplos de abordar um documento, não isolá-lo do conjunto de monumentos de que faz parte para que, assim, ele possa, de fato, contribuir para uma história total.

Em seus estudos sobre o discurso, Foucault afasta possibilidade de se definir a linguagem como simples sistema de comunicação de signos, veículo de um sentido já-lá que suponha uma "providência pré-discursiva". Nega, também, a existência de um sujeito ideológico "que pensa, que conhece e que o diz" (1997, p. 74). É 
evidente seu esforço para vincular o objeto discursivo ao que chama de "prática" e em identificá-lo como um "sistema de formação" (1997, p. 98). Recusa-se a trabalhar o discurso desvinculado do sistema de relações que o estruturam e o constituem; por isso, busca um conjunto de regras que definem as condições de possibilidade dos enunciados, os critérios de sua organização, as passagens de uma organização a outra (1997, p. 167). Isto é, partindo da definição do discurso como "regularidades de uma prática", propõe a busca das regras de sua organização interna e de sua articulação com outras práticas discursivas e também com as não-discursivas.

\section{A Projeção do Outro no Discurso}

Ocorrem grandes mudanças nos estudos lingüísticos a partir do momento em que se percebe a existência de uma dualidade constitutiva na linguagem: embora reconhecendo-se seu caráter formal, passa-se a considerar, então, ser ela simultaneamente atravessada por entradas subjetivas e sociais. Há, a partir daí, um esforço para se compreender o fenômeno da linguagem num nível exterior à bipolarização saussureana, e negar à língua uma condição de neutralidade e de centro da produção de sentido. A nova instância buscada é a do discurso, por ser onde melhor evidencia a associação entre os níveis lingüístico e extralingüístico. Longe de ser secundária, a ligação entre as "significações" de um texto e suas condições sócio-históricas é, na verdade, constitutiva das próprias significações, pois ser o discurso o ponto de articulação entre os processos ideológicos e os fenômenos lingüísticos.

$\mathrm{Na}$ condição de parte integrante do ato de enunciação, passa-se a considerar a existência de um Outro cuja função é fundamental na constituição do significado: através dele podem-se apreender as relações intrínsecas entre o lingüístico e o social. A proposta de Bakhtin foi que se estudasse a relação entre a lingüística e o social para se compreender a estreita vinculação da linguagem à ideologia. O ideológico estaria situado no espaço entre a coisa representada e o signo que a representa na linguagem, isto é, entre a coisa e a sua representação sígnica. 


\section{O Tratado e Suas Condições de Produções}

O corpus a ser analisado neste trabalho, o Tratado de Gabriel Soares de Sousa (1987), apresenta características marcantes do discurso sobre o Novo Mundo presente na crônica de viajantes renascentistas produzida no período imediato à sua descoberta. Em seus conteúdos e formas de expressão repercute o estremecimento de determinadas estruturas de pensamento, consideradas inabaláveis antes que o europeu se lançasse em sua empreitada pelo além-mar.

$\mathrm{Na}$ nova terra que veio a encontrar, tudo era diferente do que conhecia antes: desde as plantas e animais até o céu, a paisagem e os costumes dos homens. O mundo mental do homem da época contrastava com a profusão de imagens a que o leitor de nossos dias está acostumado: assim, para que seus leitores de então pudessem ter a visão das formas estranhas, exóticas, e nunca sequer sonhadas do mundo novo, enunciadores como Gabriel Soares de Sousa excitavam e estimulavam o seu imaginário até então inspirado num universo de imagens visuais bastante reduzido. Esse universo se resumia "às iluminuras dos manuscritos, à iconografia cristã, às ocasionais pinturas murais, aos retratos a óleo, às raras gravuras que ilustravam os raros livros recém-publicados por uma imprensa nascente" (CARDOSO, 1986, p. 12). Dispondo apenas do instrumento da palavra para ir construindo as imagens mentais dos leitores, os escritores da época procuravam sempre encontrar algum tipo de semelhança com as coisas já conhecidas deles, o que às vezes, porém, resultava falho e insuficiente.

Soares de Sousa teria vindo para o Brasil na armada comandada por Francisco Barreto, em 1569, o qual seguiria viagem daqui para Moçambique. Fixou-se na Bahia onde, de simples colono, se tornou proprietário de terras, de plantações de cana e de engenhos de açúcar em Jaguaripe e Jequiriçá. Foi casado com Ana de Argolo, com quem não teve filhos. Não tinha formação escolar: seus relatos sobre as terras brasileiras eram resultado do conhecimento adquirido diretamente nas inúmeras viagens que realizou pelo território da colônia. Terminou de escrever seu Tratado em 1587, enquanto aguardava autorização real para explorar minas de pedras preciosas, texto que apenas veio a ser publicado em Lisboa, no ano de 1825. Embora alguns dos dados históricos que apresenta sejam incompletos, as 
informações que traz sobre lugares, plantas, animais e, especialmente, sobre as diferentes nações indígenas compõem um documento incomparável sobre o primeiro século do Brasil.

\section{A Formação Discursiva da Crônica Renascentista}

Os relatos que se seguem à descoberta da América produzem-se num universo de formações discursivas cujos deslocamentos e fronteiras se movem ao sabor dos embates das lutas ideológicas da época. As diferentes formas de se enunciar a natureza da terra, a situação de povoamento, a condição do índio e suas relações com o homem branco, ou ainda a catequese, inscrevem-se no conjunto dessas formações discursivas. Em outras palavras, com base em seu interdiscurso, podem-se delinear as principais características da formação discursiva a que estão atrelados os textos cronísticos do quinhentismo.

As descrições e comentários sobre os costumes indígenas contidos em relatos de viajantes ou em cartas de missionários relacionam-se com o interdiscurso do conhecimento científico da época, dos interesses políticos em jogo, dos ensinamentos religiosos etc. É preciso ter em conta, nesse contexto de relações textuais, uma formação ideológica dominante em função de cujas determinações seus sujeitos enunciadores se expressam quanto ao que "pode e deve ser dito", naquele lugar historicamente determinado. Premido por injunções desse tipo, os posicionamentos dos sujeitos enunciadores assim constituídos soam às vezes contraditórios, pois o mesmo texto pode inscrever-se, simultaneamente, em diferentes formações discursivas: daí as variações de sentido que podem apresentar.

É compreensível que, para os primeiros europeus na América, fosse difícil, por exemplo, relacionar dados como o tipo de envolvimento que o índio tinha com o trabalho e o fato de terem aparência robusta e saudável: para eles, apenas a bondade da terra podia explicar essa existência sem trabalho e, assim mesmo, provida de recursos de sustento. Pela primeira vez, estavam tendo registro de que a natureza não agride o homem, de que tudo estava disponível, de que os mantimentos eram inesgotáveis e que, por isso, se podia viver e folgar, enquanto o trabalho podia se fazer desnecessário. Os recursos 
enunciativos de que se vale o discurso cronístico português, a que nos referimos a seguir, trazem indícios que permitem caracterizar o modo como era visto o homem americano no instante primordial de sua inscrição na História do pensamento ocidental.

\section{A Construção Discursiva da Historicidade do Índio}

Na primeira parte do Tratado, os capítulos em que o autor faz descrições das tribos indígenas que habitavam a costa brasileira apresentam-se justapostos aos que descrevem cada uma das capitanias hereditárias. A exemplo destes, vêm dispostos numa seqüência narrativa que simula a trajetória de uma viagem marítima pelo litoral desde a região nordeste até o sul da colônia. Constata-se, também, a recorrência das projeções enunciativas ${ }^{1}$ tanto na abertura como no encerramento dos capítulos do Tratado que descrevem as nações indígenas, o que tem por função ir assinalando e comentando, com os leitores, a ordenação e a forma de tratamento por meio das quais se enuncia o tema indígena.

As marcas de tempo, lugar e pessoa presentes nessas projeções enunciativas representam-se no texto por adjuntos adverbiais e formas verbais da $1^{a}$ pessoa do plural. Os deslocamentos do tempo narrativo para momentos de referência posteriores aos da enunciação costumam ser indicados ora pela forma verbal do futuro do presente, ora pelo presente do modo subjuntivo, o que produz o sentido de probabilidade; a indicação de deslocamentos temporais para o futuro, em geral, está enunciada por expressões adverbiais de lugar que remetem a capítulos situados mais adiante na seqüência enunciativa. É o que se pode observar, por exemplo, em passagens como essas:

este gentio é da mesma cor baça, e tem a vida e costumes dos potiguares e a mesma língua, que é em tudo como a dos tupinambás, em cujo título se dirá muito de suas gentilidades (SOUSA, p. 62);

\footnotetext{
${ }^{1}$ Tratam-se de embreagens, procedimento lingüístico-discursivo que consiste na neutralização da dimensão do enunciado pelo eu-aqui-agora, dimensão do enunciador e do enunciatário do discurso (GREIMAS, 1979).
} 
parece que não é bem que passemos adiante do rio de São Francisco sem dizermos que gentio é este caeté, que tanto mal tem feito aos portugueses nesta costa, o que agora cabe dizer deles (ibidem, p. 61);

parece razão que não passemos avante sem declarar que gentio é este a quem chamam aimorés (ibidem, p. 78);

tem esse gentio muita parte dos costumes dos tupinambás... e outras gentilidades muitas que, por escusar prolixidade, as guardamos para se dizerem uma só vez (ibidem, p. 96);

ainda que pareça ser já fora do seu lugar tratar aqui do gentio tamoio, não lhe cabia outro, por a costa da terra que eles senhorearam passar além do Rio de Janeiro até Angra dos Reis, pelo que se não podia dizer deles em outra parte mais acomodada. (ibidem, p. 109)

A marca enunciativa do tempo pretérito é construída, nessas embreagens, pelas formas compostas do particípio acompanhado de verbos no presente do indicativo. Com os empregos de "estar" e "ficar", os enunciados que se referem à tribo caeté se apresentam como uma etapa já encerrada do fazer enunciativo. $\mathrm{O}$ emprego dos adjuntos "já" e "até" projeta o sentido de proximidade entre situações já enunciadas anteriormente e o tempo presente da enunciação, ressaltando sua repercussão nesse "agora":

e como no título dos tupinambás se conta por extenso a vida e costumes, que toca a maior parte do gentio que vive na costa do Brasil, temos que basta o que está dito até agora dos caetés (SOUSA, p. 63);

já fica dito como os tamoios são fronteiros de outro gentio, que se chamam os guaianases (ibidem, p. 115);

atrás fica dito como os carijós são contrários dos guaianases, e como se matam uns aos outros; agora cabe aqui dizer deles o que se pode alcançar e saber de sua vida e costumes (ibidem, p. 119); já fica dito como o gentio tupiniquim senhoreou e possuiu a terra da costa do Brasil (ibidem, p. 87).

Em outras seqüências, os deslocamentos do ponto de vista do sujeito enunciador fazem com que se confundam os espaços 
do enunciado enunciado e da enunciação enunciada ${ }^{2}$. O sentido de inclusão do sujeito enunciatário resultante do emprego de verbos na $1^{\mathrm{a}}$ pessoa do plural força o leitor a compartilhar, passo a passo, a evolução do fazer enunciativo, como se também ele estivesse participando da cena do enunciado. Além disso, a perífrase com o verbo "ter" acompanhado de particípio reforça o caráter iterativo (TRAVAGLIA, 1985, p. 205) do relato sobre o território dominado pelos goitacases que foi acrescido ao enunciado do texto:

e como eles são tão esquivos inimigos de todo o gênero humano, não foi possível saber mais de vida e costumes, e o que está dito pode bastar por ora; e tornemos a pegar da costa, começando dos Ilhéus por diante (SOUSA, p. 80);

pois que temos declarado quase toda a costa que senhoreavem os goitacaseses, não é bem que nos despeçamos dela passando por eles, temos dito parte dos danos que fizeram aos povoadores do Espírito Santo aos da Paraíba (ibidem, p. 95)

O procedimento da denegação é utilizado com insistência nas descrições dos costumes da sociedade local nas debreagens ${ }^{3}$ que projetam a figura do índio como actante. O olhar que se lança aí sobre o homem americano denota a expectativa de encontrar refletido em cada detalhe de seu cotidiano simulacros dos valores da sociedade branca européia da época, os quais funcionam como uma espécie de marco de referência do fazer enunciativo. As negações e referências enfáticas à ausências deixam implícita a rejeição do cronista-enunciador de certos hábitos sociais dos índios, bem como seu desacordo em relação à sua organização econômica e militar, e até a alguns de seus hábitos lingüísticos:

2 Para a semiótica greimasiana, o "enunciado enunciado" corresponde ao lugar, aos atores e ao tempo da cena construída pela enunciação em oposição ao euaqui-agora em que se situa. Já a "enunciação enunciada" corresponde à explicitação, no discurso, da instância em que o mesmo está sendo produzido (GREIMAS, 1979).

${ }^{3}$ A "debreagem" compreende o movimento do foco enunciativo para fora da instância da enunciação: é, portanto, a ação do sujeito enunciado que provoca uma disjunção para a cena do enunciado (GREIMAS, 1979). 
não tem barbas nem mais cabelos no corpo que os da cabeça, porque os arrancam todos... não vivem estes bárbaros em aldeias, nem casas, como o gentio, nem há quem lhas visse nem saiba, nem desse com elas pelos matos até hoje... não costumam estes alarves fazer roças, nem plantar alguns mantimentos; mantêm-se dos frutos silvestres e da caça que matam, a qual comem crua ou mal assada, quando têm fogo; machos e fêmeas todos andam tosquiados e tosquiam-se com umas canas que cortam muito... a sua fala é rouca da voz, a qual arrancam da garganta com muita força, e não se poderá escrever... não pelejam com ninguém de rosto a rosto; toda a sua briga é atraiçoada... (SOUSA, p. 79);

não se ocupam em grandes lavouras; mantêm-se estes selvagens de caça e peixe do rio, que matam... não consentem cabelos nenhuns no corpo, senão os da cabeça (ibidem, p. 96)

Nos enunciados que confrontam, nesses vários capítulos, a situação dos índios dos primeiros tempos da colônia com uma fase cronológica posterior, têm lugar micro-embreagens que, ao inscreverem no texto, o tempo "agora" da enunciação, indicam que, na época em que o Tratado foi escrito, grande parte das tribos que habitaram a costa brasileira já havia sido expulsa do litoral para o interior do território da colônia. Os relatos cronísticos tratam, porém, de modo reticente as possíveis causas dessa expulsão, dando-as apenas como resultado das guerras por território que as tribos travavam entre si. Apenas muito raramente, como na última das citações abaixo, a enunciação deixa implícito que a ação povoadora dos homens brancos, devidamente amparada nos objetivos espirituais da religião, poderia ter sido a causadora dessa situação:

(caetés) e desta maneira se consumiu este gentio, do qual não há agora senão o que se lançou muito pela terra adentro, ou se misturou com seus contrários sendo seus escravos, ou se aliaram por ordem de seus casamentos (SOUSA, p. 62);

(papanases) este gentio viveu ao longo do mar entre a capitania de Porto Seguro e a do Espírito Santo, donde foi lançado pelos tupiniquins, seus contrários, e pelos goitacases, que também o eram, e são hoje, seus inimigos, e uns e outros lhe fizeram tão cruel guerra que os fizeram sair para o sertão, onde agora têm sua vivenda (ibidem, p. 96); 
(tamoios) ao tempo que os portugueses descobriram esta província do Brasil, senhoreavam a costa dele desde o rio do cabo de São Tomé até a Angra dos Reis; do qual limite foram lançados para o sertão, onde agora vivem (ibidem, p. 109);

(tupiniquins) o qual tem agora despovoado toda esta comarca, fugindo dos tupininambás, seus contrários, que os apertaram por uma banda, e aos aimorés, que os ofendiam por outra: pelo que se afastaram do mar, e, fugindo ao mau tratamento que lhes alguns homens brancos faziam, por serem pouco tementes a Deus (ibidem, p. 87)

No início do quarto parágrafo do capítulo 19, o relato sobre os inúmeros "danos" causados pelos caetés aos portugueses termina com uma debreagem em que se atribuiu à intervenção divina a responsabilidade pela infelicidade desses indígenas. Ao lado desse enunciado que retoma o tema da religiosidade no espaço enunciativo, a inserção de uma micro-embreagem, expressa pela primeira pessoa do pronome demonstrativo, revela a importância atribuída pelo autor ao relato sobre a expulsão dos caetés, que vem aí antecipado: "cujos danos Deus não permitiu que durassem muito tempo; mas ordenou de os destruir desta maneira" (SOUSA, p. 62).

A perífrase verbal composta pelo verbo "ir" seguido de gerúndio serve para marcar, no mesmo parágrafo, o aspecto durativo e a idéia de progressividade em relação a uma determinada situação (TRAVAGLIA, 1985, p. 224). É esse o sentido que adquire o relato da execução paulatina dos prisioneiros dos índios, ou seja, como acontecimentos episódicos que obedeciam a rituais ditados pela tradição. Por meio dos sentidos de movimento contidos nos verbos "ir" e "vir", que aparecem no mesmo enunciado, percebe-se a ancoragem da voz enunciativa num ponto de referência à distância da cena do enunciado onde estão debreados os grupos indígenas. A perífrase "acabou de desbaratar" tem sentido perfectivo e não apresenta a noção de passado recente (TRAVAGLIA, 1985, p. 257) como poderia parecer, pois a preposição "de" vem aí empregada com o mesmo sentido da preposição "por", apresentando-se, assim, a intervenção do governador-geral Duarte Coelho como causa determinante e definitiva do processo de aniquilação dos caetés: 
destes cativos iam comendo os vencedores quando queriam fazer suas festas, e venderam deles aos moradores de Pernambucos e aos da Bahia infinidade de escravos a troco de qualquer coisa, ao que iam ordinariamente caravelões de resgate, e todos vinham carregados desta gente, a qual Duarte Coelho de Albuquerque por sua parte acabou de desbaratar. (SOUSA, p. 62)

No enunciado sobre as freqüentes mortes de portugueses causadas pelos aimorés, inscreve-se o caráter iterativo e não-acabado expresso pela perífrase do verbo "ter" no presente do indicativo seguido de particípio passado (TRAVAGLIA, 1985, p. 206), o que reforça a idéia da longa duração desses ataques denotada também pelo adjunto adverbial de tempo:

e cada um trabalha por se pôr em salvo, o que também fazem os homens brancos, dos quais têm morto estes alarves de vinte e cinco anos a esta parte mais de trezentos homens portugueses e de três mil escravos. (SOUSA, p. 80)

No mesmo capítulo sobre os índios aimorés, nota-se um esforço da enunciação para destacar as conseqüências futuras dos constantes ataques desses índios: daí a apresentação da situação em seu desenvolvimento gradual e progressivo por meio da perífrase de aspecto durativo constituída pelo verbo “ir" acompanhado de gerúndio, efeito de expressão lingüística já apontado por Travaglia (1985, p. 224). Produz-se, assim, um enunciado que antecipa como inevitáveis possíveis prejuízos que podem vir a ser causados nas regiões mais povoadas: "e se se não busca algum remédio para destruírem estes alarves, eles destruirão as fazendas da Bahia, para onde vão caminhando de seu vagar" (SOUSA, p. 80).

Reitera-se, no último enunciado do capítulo 58, a perspectiva da enunciação baseada no espaço do continente europeu, o que se evidencia nas debreagens espaciais enunciativas expressas por meio de verbos que denotam deslocamento no espaço. Nesse caso, depois de suspender a ancoragem do ponto de vista enunciativo no espaço geográfico colonial, o emprego do verbo "trazer" provoca um deslocamento para o lugar em que se localizam os principais inimigos dos portugueses: "nestes dois rios costumavam os franceses 
resgatar cada ano mil quintais de pau-brasil, aonde carregavam muitas naus, que trażiam para França" (ibidem, p. 110).

A postura usual do sujeito enunciador, de manter-se debreado no âmbito do enunciado enunciado, é novamente suspensa, agora com o emprego do demonstrativo de $3^{\text {a }}$ pessoa no capítulo 68 , que trata dos índios carijós. O que explica a localização desses actantes no espaço "lá" do enunciado e o distanciamento da figura do enunciador é o quase total desconhecimento dos portugueses do século XVI sobre a região sul do Brasil, que era, então, habitada por essa comunidade: "vivem estes índios em casas em cobertas e tapadas com cascas de árvores, por amor do frio que há naquelas partes" (ibidem, p. 119).

Reunidos no "título 17", intitulado "Notícia etnográfica do gentio tupinambá que povoava a Bahia", da segunda parte do Tratado, os capítulos de números 147 a 177 apresentam relatos sobre essa nação indígena com a qual o autor certamente teve contatos mais freqüentes no período em que viveu no Brasil. Afinal, suas propriedades agrícolas situavam-se em região vizinha às terras dessa tribo.

\section{As Marcas do Fazer Enunciativo no Relato Quinhentista}

O modo de construção e os sentidos desencadeados pelo enunciado cronístico pode ser percebido particularmente nas estruturas de funcionamento de seu discurso. Nesses capítulos voltados para a descrição da vida indígena, percebe-se que a construção de sentidos resulta, em grande parte, da recorrência de mecanismos lingüísticos como a projeção do fazer enunciativo no enunciado. Assim é que, já no próprio subtítulo, instaura-se uma embreagem espacial enunciativa constituída por adjunto adverbial, que vem antecipar o tema predominante nas unidades seguintes do texto: "daqui por diante se trata da vida e costumes do gentio da terra da Bahia" (SOUSA, p. 299). No enunciado do discurso de introdução, o uso do pretérito imperfeito do indicativo de "ser" pelo presente do indicativo, que expressa um desejo ou uma vontade do enunciador em relação à matéria narrada (FIORIN, 1996, p. 209), ressalta o empenho com que o cronista se dispõe a fazer esse relato. A projeção de uma instância temporal anterior, a da referência discursiva aos tupinambás, enuncia-se através das 
perífrases verbais de "ter" seguido de particípio, com o que fica marcada a aspectualidade imperfectiva iterativa, cursiva do nãoacabado (TRAVAGLIA, 1985, p. 206), enquanto que a embreagem para o lugar da enunciação é construída com o emprego de adjuntos adverbais ("neste tratado", "daqui"). A embreagem da pessoa do enunciador na primeira pessoa do plural dos verbos "dizer", "ter" e "começar" marca a inclusão da pessoa do enunciatário no fazer enunciativo:

já era tempo de dizermos quem foram os povoadores e possuidores desta terra da Bahia, de que se tem dito tantas maravilhas, e quem são estes tupinambás tão nomeados, cuja vida e costumes temos prometido por tantas vezes neste tratado, ao que começamos satisfazer daqui pôr diante. (SOUSA p. 299)

No capítulo 172, repete-se uma micro-embreagem em que a projeção de um "nós" inclusivo do enunciador, ao mesmo tempo em que destaca um dos aspectos do ritual indígena de execução de um prisioneiro, anuncia o relato da execução que virá num dos capítulos seguintes - "e antes de chegar a execução, contemos como se prepara o matador" (SOUSA, p. 326). Na introdução do capítulo 177, instaurase uma embreagem espacial enunciativa com o adjunto "aqui", com a qual o cronista-enunciador procura justificar para os leitores a inclusão de uma nova informação sobre os tupinambás: "ainda que pareça fora de propósito o que se contém neste capítulo, pareceu decente escrever aqui o que nele se contém, para se melhor entender a natureza e condição dos tupinambás" (SOUSA, p. 331).

No início do capítulo 150, a referência às divisões e inimizade entre os diferentes grupos de tupinambás enuncia-se por uma oração adverbial concessiva, na qual os verbos do tempo do pretérito perfeito 2 vêm substituindo a forma composta do imperfeito do subjuntivo. Enunciando-se a ação dos índios por intermédio do modo indicativo, evita-se o efeito de sentido de mera pressuposição ou hipótese, destacando-se sua condição de situação do passado cujo efeito ainda repercute no tempo presente: 
ainda que os tupinambás se dividiram em bandos, e se inimizaram uns com outros, todos falam uma língua que é quase geral pela costa do Brasil, e todos têm uns costumes em seu modo de viver e gentilidades. (SOUSA, p. 302)

Com o emprego da perífrase verbal de infinitivo com o verbo "haver" + preposição "de", é produzido o sentido de obrigação lógica e moral, além de se assinalar a certeza quanto à realização de algo (ALMEIDA, 1980, p. 143). Na descrição de variados aspectos da vida dos tupinambás referidos no enunciado, os sentidos que essas perífrases usualmente exprimem são os da obrigação moral prevista nas tradições da cultura indígena, quer em relação à escolha dos chefes, quer nos procedimentos rituais de casamento, de guerra, ou em execuções de inimigos e funerais:

em cada aldeia dos tupinambás há um principal. Este principal há de ser valente homem para o conhecerem por tal (SOUSA, p. 303);

e em cada aldeia há um cabeça, que há de ser índio antigo e aparentado, para lhe os outros que vivem nestas casas terem respeito (ibidem, p. 303);

e ainda que uma moça destas seja deflorada por quem não seja seu marido, ainda que seja em segredo, há de romper os fios da sua virgindade, que de outra maneira cuidará que a leva logo o diabo (ibidem, p. 305);

todos os seus fundamentos são como farão guerra aos seus contrários; para o que se ajuntam no terreiro da sua aldeia; onde assentam a que parte bão de ir dar a dita guerra... e as mulheres entendem em lhes fazerem a farinha que bão de levar, a que chamam de guerra (ibidem, p. 320);

todo tupinambá que matou na guerra algum contrário, tanto que vem para casa, e é notório aos moradores dela da tal morte do contrário, costumam, em o matador entrando em casa, arremessarem-se todos ao seu lanço e tomarem-lhe as armas e todas as suas alfaias de seu uso, ao que ele não há de resistir por nenhum caso, e há de deixar levar tudo sem falar palavras... e ao dia que se hão de beber os vinhos se tosquia o matador e tira o dó (ibidem, p. 324). 
O uso dessa perífrase de infinitivo enfatiza, em outros enunciados, a atitude de indolência e passividade com que o indígena se entregava a doenças que considerava fatídicas e incuráveis. Na citação, a micro-embreagem em que o verbo "haver" é empregado no pretérito perfeito 2 em lugar do futuro do pretérito, neutralização que acaba apresentando como certo e acabado o que é incerteza (FIORIN, 1996, p. 202). Esta ocorrência denota, no comentário do narrador, uma avaliação depreciativa desse comportamento tão comum entre os índios:

nestas festas se cantam as proezas do defunto e defunta... mas este sentimento houveram de ter os vivos dos mortos, quando estavam doentes; mas são tão desamoráveis os tupinambás que, quando algum está doente, e a doença é comprida, logo aborrece a todos os seus, e curam dele muito pouco... ntes o desamparam, dizendo que pois há de morrer, e não tem remédio. (SOUSA, p. 331)

O mesmo recurso de linguagem pode ser empregado, também, quando o enunciador faz referência à oferta de trabalho e conhecimento indígena ao homem branco, indispensável nas situações de perigo em que este se envolvia durante incursões pela mata:

e por os tupinambás terem este conhecimento da terra e do fogo, se faz muita conta deles, quando se oferece irem os portugueses à guerra a qualquer parte, onde os tupinambás vão sempre adiante, correndo a terra por serem de recado, e mostrando à mais gente $\mathrm{O}$ caminho por onde bão de caminhar, e o lugar onde se bão de aposentar cada noite. (SOUSA, p. 320)

Nas descrições de instrumentos e práticas sociais dos indígenas, as debreagens enuncivas a lugares de outros continentes que já haviam sido descobertos pelos portugueses instauram pontos de referência espacial que criam um efeito de sentido de maior verdade e atualidade:

fazem estes índios umas cordas tecidas que têm o feitio dos cabos de cabresto que vêm de Fez.(SOUSA, p. 312); 
os contrários que os tupinambás cativam na guerra metem-nos em prisões, as quais são cordas de algodão grossas as quais são tecidas como os cabos dos cabrestos de África (ibidem, p. 324); e assim se revezam todos os que não a têm (a cangoeira), com ela; o que estes índios fazem por autoridade, como os da Índia comem o bétele, em semelhantes ajuntamentos; o que também fazem muitos homens brancos e todos os mamelucos. (ibidem, p. 317)

A adesão dos actantes indígenas ao fazer cognitivo do sujeito observador da enunciação fica implícita em formulações enunciativas de certas embreagens e debreagens. É o que se pode observar no primeiro capítulo, o de número 147 deste título, que trata dos tupinambás, onde os sujeitos "índios muito antigos" vêm projetados como adjuvantes da instância enunciativa, sendo esta representada por um sujeito indeterminado, procedimento que se repete no capítulo 149, onde os "tupinambás e tupinaés" aparecem como adjuvantes do branco:

os primeiros povoadores que viveram na Bahia de Todos os Santos e sua comarca, segundo as informações que se têm tomado dos índios muito antigos, foram os tapuias(Sousa, p. 299);

e assim foram possuídores desta província da Bahia muitos anos, fazendo guerra a seus contrários até a vinda dos portugueses a ela; dos quais tupinambás e tupinaés se têm tomado esta informação, em cuja memória andam estas histórias de geração em geração. (ibidem, p. 300)

As marcas dessa colaboração inscrevem-se, freqüentemente, por debreagens actanciais enunciadas por orações subordinadas adjetivas, em que se atribui ao próprio índio a responsabilidade pelo ato de nomear. Assegura-se, desse modo, o sentido de verdade de conteúdos relativos a diferentes aspectos da vida indígena, como habitação, manufatura, utensílios, doenças, táticas de guerra, parentesco, etc.:

e como escolhe o sítio a contentamento dos mais antigos, faz o principal sua casa muito comprida, a que os indios chamam pindoba (SOUSA, p. 303); 
o seu vinho principal é de uma raiz a que chamam aipim (ibidem, p. 311);

andam dando o vinho em uns meios cabaços, a que chamam cuias, aos que andam cantando (ibidem, p. 311);

fazem cestos de varas, a que chamam samburá (ibidem, p. 312);

fazem-lhe pôr de redor outra contracerca de rama e espinhos muito liada com madeira que metem no chão, a que chamam caiçá (ibidem, p. 322);

e a mão que não come seu próprio filho, a que estes índios chamam cunhambira, que quer dizer filho do contrário, têm-na em ruim conta (ibidem, p. 325).

Quando, porém, o relato incide diretamente sobre a vida espiritual dos indígenas, um dos pontos de maior atrito nas relações entre índios e brancos no século XVI, evidenciam-se marcas de juízos de valor engendrados pelo sujeito da enunciação. Sua vinculação a preceitos espirituais do cristianismo faz com que não consiga reconhecer o verdadeiro significado dos rituais religiosos dos "bárbaros" americanos:

entre este gentio tupinambá há grandes feiticeiros, que têm este nome entre eles, por lhe meterem na cabeça mil mentiras... os quais, pela maior parte, não sabem nada, e para se fazerem estimar e temer tomam este ofício, por entenderem com quanta facilidade se mete em cabeça a esta gente qualquer coisa. (SOUSA, p. 314).

A projeção da figura do diabo no enunciado que descreve a atividade dos pajés ora depende do ponto de vista de um actante indígena, ora é feita por asserções da própria voz enunciativa, o que produz a impressão de que não se trata apenas de um delírio ou da visão mitificada do gentio fanático, mas de uma presença que é abonada como real pelo próprio narrador. As crendices indígenas são assimiladas pelo discurso segundo os critérios de representação de fé no catolicismo, o que explica a ocorrência de enunciados que ressaltam a rusticidade dos credos indígenas:

mas há alguns que falam com os diabos, que os espancam muitas vezes, os quais os fazem muitas vezes ficar em falta com o que dizem... muitas vezes acontece aparecer o diabo a este gentio, em 
lugares escuros, e os espanca de que correm de pasmo; mas a outros não faz mal, e lhes dá novas de coisas sabidas. (SOUSA, p. 314)

Ao menos nas descrições dos diálogos que compõem as cerimônias rituais da antropofagia, modifica-se o estilo enunciativo de acobertamento da voz do sujeito indígena. Aí a concessão da palavra ao indígena torna-se necessária para tornar menos imprecisos os sentidos da cerimônia mais importante das crenças do novo mundo: com isso, o cronista procura facilitar o entendimento do leitor do Tratado. Ao invés, porém, de dar a palavra diretamente ao actante indígena, o enunciador, sem abrir mão da posição hierárquica do discurso citante em relação ao discurso citado, serve-se do discurso indireto ${ }^{4}$. Assim, embora o texto tenha duas fontes enunciativas, não ocorre uma debreagem interna, como no discurso direto, pois a parte da enunciação que é de responsabilidade dos índios é substituída por um equivalente semântico que se integra à enunciação. Desse modo, o enunciador introduz, com os verbos dicendi, um resumo do que é dito pelos vários participantes da celebração antropofágica, construindo sua própria versão do que é enunciado pelo falante citado para demonstrar a formação ideológica a que ele está vinculado:

cantam suas cantigas vituperando o que há de padecer e exalçando
o narrador, dizendo suas proezas e louvores, e como estes cativos
vêem chegada a hora em que hão de padecer, começam a pregar e
dizer grandes louvores de sua pessoa, dižendo que já estão vingados
de quem os há de matar, contando grandes façanhas suas e mortes
que deram aos parentes do matador, ao qual ameaçam e a toda a

\footnotetext{
${ }^{4}$ No subtítulo "A pessoa transformada" do capítulo que trata da categoria pessoal da enunciação, José Luiz Fiorin (1996) fala da subordinação do discurso citado à enunciação do discurso citante no discurso indireto. Nele, segundo Fiorin, "não há dois $e$, mas apenas uma fonte enunciativa que não diz eu (locutor), responsável por parte da enunciação de um eu "como acontece no discurso direto. Há uma única enunciação, com o que apagam-se todos os traços enunciativos da enunciação desse interlocutor que foi subordinada à enunciação do narrador: "no texto, só existe a subjetividade do narrador" (FIORIN, 1996, p. 75).
} 
gente da aldeia, dizendo que seus parentes os vingarão... onde lhe as velhas dizem que se farte de ver o sol, pois tem o fim tão chegado; ao que o cativo responde com grande coragem, que pois ele tem vingança da sua morte tão certa, que aceita o morrer com muito esforço. (SOUSA, p. 326)

A contraposição de formações discursivas se evidencia mais claramente nos enunciados de rejeição aos preceitos morais e espirituais em vigor na sociedade indígena. Aqui, novamente, é o emprego das denegações o recurso que mais claramente deixa marcados juízos de valor derivados da formação discursiva a que o texto cronístico está relacionado. Ao negar, o enunciador delimita os pontos de maior atrito no confronto ideológico entre as culturas de brancos e índios, o que pode advir de comparações relativas aos costumes à mesa:

... e enquanto comem não bebem vinho, nem água, o que fazem depois de comer. Quando os tupinambás comem à noite não praticam em coisa alguma quando comem, senão depois de comer... este gentio não come carne de porco, dos que se criam em casa, senão os escravos criados entre os brancos. (SOUSA, p. 310)

ou da utilização de métodos pedagógicos e formas de relação social diferentes dos que estavam prescritos pelos hábitos culturais do homem branco:

não dão os tupinambás a seus filhos nenhum castigo, nem os doutrinam, nem os repreendem por coisa que façam (SOUSA, p. 307);

no despojo desta guerra não tem o principal coisa certa, e cada um leva o que pode apanhar (ibidem, p. 322).

É difícil, para o cronista-enunciador, compreender as razões de uma sociedade tão peculiar como a americana; por isso, apenas lhe resta contestar tudo o que nela se diferencia de seus próprios padrões morais e espirituais. Como parâmetro para retratar o diferente, apenas consegue adotar o que já conhece; daí o seu grande empenho em descobrir faltas e a sua dificuldade para enxergar o que há de 
inédito na realidade do novo mundo. Por isso, denega, enquanto enunciador, tudo aquilo que não tem similaridade com os padrões sexuais restritivos, com a desconfiança no trato com o Outro, a mistificação no tratamento de assuntos de estado, componentes predominantes na formação ideológica da sociedade européia do século XVI a que está vinculado:

são os tupinambás tão luxuriosos que não há pecado de luxúria que não cometam... e não se contentam com uma mulher, mas têm muitas... e em conversações não sabem falar senão nestas sujidades, que cometem cada hora... e não contentes estes selvagens de andarem tão encarniçados neste pecado, naturalmente cometido, são muito afeiçoados ao pecado nefando, entre os quais se não têm por afronta (Sousa, p. 308);

quando entra algum hóspede em casa dos tupinambás, logo o dono do lanço da casa, onde ele chega, lhe dá a sua rede e a mulher lhe põe de comer diante, sem lhe perguntarem quem é, nem de onde vem, nem o que quer (ibidem, p. 316);

quando o principal da aldeia quer praticar algum negócio de importância, manda recado aos índios de mais conta, os quais se ajuntam no meio do terreiro da aldeia, onde também se chegam os que querem ouvir estas práticas, porque entre eles não há segredo (ibidem, p. 317).

O emprego veemente das denegações, nas referências à forma de linguagem do índio, demonstra a confiança que o sujeito enunciador tem na palavra enquanto instrumento imprescindível para a fundação do real. Uma vez que apenas nomeando o homem pode estar de posse das coisas, considera que, para os índios, isso sempre será impossível, pois thes falta o essencial, que é a palavra:

faltam-lhe três letras do ABC, que são F, L, R grande ou dobrado, coisa muito para se notar; porque, se não têm $\mathrm{F}$, é porque não têm fé em nenhuma coisa que adorem; nem os nascidos entre os cristãos e doutrinados pelos padres da Companhia têm fé em Deus Nosso Senhor, nem têm verdade, nem lealdade a nenhuma pessoa que lhes faça bem. E se não têm L na sua pronunciação, é porque não têm lei alguma que guardar, nem preceitos para se governarem; e cada um fez lei a seu modo, e ao som da sua vontade; sem haver 
entre eles leis com que se governem, nem têm leis uns com os outros. E se não têm esta letra $\mathrm{R}$ na sua pronunciação, é porque não têm rei que os reja, e a quem obedeçam, nem obedecem a ninguém, nem ao pai o filho, nem o filho ao pai, e cada um vive ao som da sua vontade. (SOUSA, p. 302)

\section{Considerações Finais}

Foucault (1997) atenta para o fato de que, no jogo estratégico de ação e reação do discurso, se fazem presentes atos de dominação, de esquiva e de luta. Segundo ele, o saber e o poder articulam-se no espaço discursivo: a fala se dá por causa de um direito reconhecido institucionalmente, enquanto que o discurso veicula um saber que é institucional e que também representa uma fonte de geração de poder. Outras de suas funções são controle, seleção, organização e redistribuição de saberes geradores de poder; para este, funciona como barreira de proteção contra as ameaças à sua permanência e hegemonia.

O intrincado conceito de ideologia tem grande importância para a Análise do Discurso, inclusive, parcialmente, na acepção marxista enquanto instrumento de dominação de classe que permite à classe dominante produzir a simulação de que as idéias que lhe são próprias são também de todos, eliminando as contradições entre força de produção, relações sociais e consciência. Necessária à dominação de classe, a ideologia aparece como uma abstração que inverte a realidade: faz o possível para criar, na mente dos homens, uma visão ilusória da realidade que a faz parecer verdadeira. Apresentase como uma manobra disfarçada em explicações teóricas e práticas que nunca se explicitam claramente, para não deixar evidentes as contradições sociais; em razão disso, os discursos, e especialmente os mais marcadamente ideológicos, compõem-se de "lacunas", "silêncios", "brancos" etc. com que se procura garantir a coerência desse sistema.

Para explicar a maneira como se inscrevem as condições sócio-históricas de produção no "exterior" lingüístico, a Análise do Discurso francesa opera com o conceito de ideologia, o qual envolve o princípio da contradição enquanto aspecto inerente à essência das relações entre grupos sociais. Não lhe interessa, porém, eliminar a 
contradição, mas fazê-la aparecer na materialidade lingüística do discurso, para poder captar as relações de antagonismo, aliança, dissimulação e absorção estabelecidas entre diferentes formações discursivas. Pelos objetivos a que se propõe, não pode deixar de ser interdisciplinar: mantém relações com as diversas tendências desenvolvidas no interior das ciências lingüísticas, articulando-se com a Pragmática, a Teoria da Enunciação, a Semântica Argumentativa, etc. Ao estudar a linguagem, não se limita a seu sistema interno e formal, preferindo enfocar as exigências que as formações discursivas, fenômenos determinantes em seu funcionamento, fazem a usuários. Estuda a linguagem em função das injunções da formação ideológica sobre o fazer discursivo de todo falante. Daí porque os conceitos de discurso e ideologia são fundamentais nesse processo de aproximação entre os estudos lingüísticos e histórico-sociais.

O papel da memória coletiva, que se tornou mais clara depois da segunda metade do século XX, com a evolução das sociedades, passa, desde então, a fazer parte das grandes questões das sociedades desenvolvidas. Como conseqüência, a memória começou a ser vista como elemento essencial naquilo que se costuma chamar de identidade individual ou coletiva, cuja busca é uma das atividades fundamentais dos indivíduos e das sociedades modernas. Segundo Le Goff (1996), o que há de original nas novas orientações da história é a forma de tratamento que se passa a dar à noção de tempo, com análises dos fenômenos do poder sob todas as suas formas e não só do político, além da reinvidicação de que, no estudo da atividade humana, sejam consideradas as condições históricas em que existe ou existiu. Os esquecimentos e os silêncios da história participam abertamente do jogo de indivíduos e das classes dominantes para assenhorearem-se da memória e do esquecimento. A importância da noção de discurso para o trabalho crítico do historiador com documentos do passado fez surgir um campo interdisciplinar, que tem provocado grandes mudanças nas relações entre historiadores e lingüistas. 


\section{Referências Bibliográficas}

ALMEIDA, J. Introdução ao estudo das perífrases verbais de infinitivo. Assis: IHPA-Hucitec, 1980.

CARDOSO, J. A empresa inaciana e a edificação da Brasilíndia. 1996. Tese (Mestrado) - Editora da Universidade do Porto, Porto.

FIORIN, J. As astúcias da enunciação. São Paulo: Ática, 1996.

FOUCAUlT, M. A Arqueologia do Saber. 5. ed. Rio de Janeiro: Forense Universitária, 1997. 239 p.

GREIMAS, A.; COURTÉS, J. Dicionário de Semiótica. São Paulo: Cultrix, 1979.

LE GOFF, J. História e Memória. Campinas. Ed. Unicamp, 1996.

PÊUCHEUX, M. Semântica e discurso: uma crítica à afirmação do óbvio. 2. ed. Campinas: Ed. Unicamp, 1995.

SOUSA, G. S. Tratado Descritivo do Brasil em 1587. 5. ed. São Paulo: Nacional, 1987.

TRAVAGLIA, L. O aspecto verbal no Português: a categoria e sua expressão. Uberlândia: Ed. Universidade Federal da Uberlândia, 1985. 